\title{
Environmental Case Study of Water Quality of Ancient Wells- Masabi Boudi and Narasimha Temple Well of Bijapur
}

\author{
Dr. Geeta. S. Patil ${ }^{1}$, Dr. S B Patil ${ }^{2}$, \\ ${ }^{1}$ Department of Botany, S B Arts and KCP Science college Bijapur, Karnataka India \\ ${ }^{2}$ Department of Chemistry S B Arts and KCP Science college Bijapur , Karnataka India
}

\begin{abstract}
Ancient historic wells or boudies, built by Adil Shahi kings in Bijapur are the huge sources of water in the drought place of northern Karnataka (India). They stand neglected and polluted. Masabi Boudi and Narasimha Temple well are two wells selected for the study. We have studied the water quality in terms of physico-chemical, biochemical, phytoplanktonic and bacteriological properties depthwise. Masabi Boudi exhibited a rare phenomenon of vertical inverse thermal stratification whereas in Narasimha Temple well winter thermal stratification broke in summer and monsoon. Phytoplankton occurrence was rare in Masabi Boudi. Desmids showed their pollution tolerance throughout the study in Masabi Boudi. Glucose, protein, creatinine, urea and uric acid in the water reads the utrophication, which resulted the growth of E-coli. Algal maximum was followed soon after the E-coli were in excess in both the wells. Chlorides, nitrates and nitrogenous content stated the rich nutritional status. The self purification of water takes place naturally as a quality control. There is a natural symmetry in the biological science between bacterioplankton and phytoplankton and high enrichment with organic matter provided a measure of stabilization to this eco-system. In all, Masabi Boudi shows better water quality than Narasimha Temple well.
\end{abstract}

Key words - Bacterioplankton, Boudi, Inverse thermal stratification, Nutritional status, Phytoplankton.

\section{Introduction}

Wells with rich water source show the existence of life and brisk activity. Above the water is a beautiful mirror for sky and Sun. This colorful, multiform mosaic of the well, provides a habitat for the wealth of flora and fauna, and enriches the landscape. Life cannot exist without water and water takes first priority of the life. Water itself is an environment. But this environment is being highly affected and disturbed due to the increased population, industrialization and urbanization which lead to the water scarcity to the human race. The eutrophication of water or pollution of water or enrichment of nutrients results in the degradation of water quality by enhanced bacterial growth. As a result of biochemical pollutants being put into the water, convert the water body into the biological deserts.

The depth wise water study of the wells is of very much less in India. Well water and ground water are the main source of drinking for about $70 \%$ of the Indian population and is considered to be less polluted. Pioneering works have been done on fresh waters but not wells. Recently the still waters, being influenced by climatic changes, with their extremely low rate of water renewal and their largely closed system are much more sensitive to pollution than running waters. Hence the well study becomes unique observation to know the impact of many environmental factors on the biotic components of the water, specially in depth profile.

The present work was undertaken in order to study the ecology of two ancient, historical wells of the Adil Shahis in Bijapur city. Bijapur, the ancient historical city of north Karnataka in India was ruled by the Adil Shahi dynasty from $15^{\text {th }}$ century to $17^{\text {th }}$ century. Bijapur situated on the deccan plateau, does show the remains of the huge wells with great depth built by the kings and meant for drinking purpose, recreation and as holy waters.

\subsection{Masabi Boudi}

This is a beautiful well built by Mohummad Adil Shah in the name of his mother and caretaker Fateeja Sultana. She was a princess from Golconda dynasty and had lot of interest in art, culture and Dakhini poetry. The king is known for his famous construction of Golgumbaz - the second biggest dome in the world. This well is situated behind Golgumbaz and at a distance of about $1 \mathrm{~km}$ from railway station. It has a square shape with an area of about 81 sq.mts. The depth is about $12 \mathrm{mts}$. The well is exposed to sunlight and there is no much disturbance created by the people.

\subsection{Narasimha Temple well}

This well is at distance of about half a $\mathrm{km}$ from Bijapur city bus station. It was built by Adil Shahis outside the fort, nearby a hindu temple of lord Narasimha. Hence the name. At present, it is in the centre of the city. It also has springs and the depth of $12 \mathrm{mts}$. The water is spread along the fort side. Adil Shahi kings have 
built a Mahal for recreation besides the well called as Asar Mahal. This beautiful archeological monument is surrounded by a garden for which the well water is used. The well has almost a lake-look at its stretch. It is exposed to open sunlight and is rich with macro vegetation like Typha and other grasses. Washing of clothes is common here. The temple wastes are also dumped in the well.

\section{Materials and Method}

The collection of the water samples were made once in a month at fixed spots from October 2008 to September 2010. The collection of samples was made between $8.30 \mathrm{am}$ to $9.30 \mathrm{am}$. Temperature was noted on the field and winklerisation was done on the spot. Other factors were analyzed immediately in the laboratory on the same day without much lapse of time. The collection of samples at depth was done by using Van Dorn water sampler. All the physico-chemical parameters were analyzed by the standard methods, 1980 and NEERI1988 manual on water and waste water analysis. Surface water samples were collected for the microbial study in sterilized containers and given to the Dept. of Micrbiology BLDEA's Medical College for the E-Coli tests. Samples of phytoplankton were collected from the surfaces and at various depths once in a month and the fixation and sedimentation were made in $4 \%$ formalin and the supernatant was decanted.

\section{Results and discussion}

The seasonal average values of the various variables in Masabi Boudi and Narasimha temple well are given in table 1 and 2.

\subsection{Water temperature}

Unique results were observed with parameter of water temperature. The range of water temperature for the two wells was almost similar. Masabi Boudi exhibited clear thermal stratification in which the temperature of the deeper strata were higher than the upper layers. Both the water bodies experienced a high water temperature by the onset of monsoons. The reason may be due to the warming up of the rocky beds in summer and the rain waters flowing through these rocky beds will attain high temperature and cause a sudden increase in the temperature in the aquatic system.

\subsection{Masabi Boudi - Temperature}

Temperature maxima were observed in the months of May, June and July. Heavy rains were recorded in these months and that may be the cause for the rise in the temperature at the surface. December and January were cold with minimum temperature at the surface. A fluctuation of $6.3{ }^{\circ} \mathrm{C}$ was noted in the surface. Such low amplitude of thermal variation throughout the study is indicative of the tropical status of the water body $(1,2)$. Water temperature decreased from the surface to $9 \mathrm{mts}$ depth. A maximum difference of $9^{\circ} \mathrm{C}$ was noted in the months of June and July. Similar observations were supported by various authors $(3,4,5$ and 6$)$. In May and June water temperature is constant at the surface $-31^{\circ} \mathrm{C}, 3 \mathrm{mts}-31^{\circ} \mathrm{C}$ and for $6 \mathrm{mts}$ and $9 \mathrm{mts}$ depth readings were not observed as the water level had fallen down. This is due to the formation of thermal stratification which is observed in summer for tropical lakes (7).

An exceptional vertical inverse thermal stratification has been attained in the months of December and January, the temperature has increased with the increase of depth $(8,9$ and 10). This may be attributed to the formation of some chemical stratification where the increase in density due to rise in temperature is not sufficient to overcome the increase due to the dissolved concentration (11). Thus in Masabi Boudi, thermal stratification is observed in few months and it shows a rare phenomenon of inverse thermal stratification, in which the temperature in the deeper strata is higher than the upper layer.

\subsection{Narasimha Temple well- Temperature}

Compared to Masabi Boudi, Narasimha Temple well is a long stretch of water, starting from the spring area of the well to the running side of the fort wall. At the beginning of the study the water samples could be collected at surface, $3 \mathrm{mts}$., $6 \mathrm{mts}$ and $9 \mathrm{mts}$. depth. But from February onwards the water level further decreased. Hence the samples collected are from the surface and $3 \mathrm{mts}$. only, till the end of the study. Narasimha Temple well exhibited an average of $26.5^{\circ} \mathrm{C}$ at surface, with the range of $25^{\circ} \mathrm{C}$ at $3 \mathrm{mts} ., 23.7^{\circ} \mathrm{C}$ at $6 \mathrm{mts}$. And $25^{\circ} \mathrm{C}$ at $9 \mathrm{mts}$. depth. A very interesting phenomenon was noted in the month of February. The water temperature recorded were lowest $\left(23^{\circ} \mathrm{C}\right.$ at surface and $22^{\circ} \mathrm{C}$ at $3 \mathrm{mts}$.). Compared to temperatures of the remaining months, February is warm and the air temperature is high. Low temperature in the month of February can be explained by "Temperature lag". Small water bodies respond quickly to the change in air temperatures (7 and 8). But Zafar 1968 (9) contends that water with thick global population or high salt content take much longer time to get heated and there will be a considerable temperature lag. 


\subsection{Vertical variation}

A decline of the temperature towards the lower strata was observed in most of the months. Due to the shallow nature of the well, it exhibited homothermal conditions in the months of April, May, June and September. The homothermal condition throughout the water column and the remaining period showing the fall in the temperature is due to the mixing of water layers (10,11 and 12). They have observed similar circulation in their studies. The growth of macrophytes like Typha at the littoral zone, continous human disturbance must also have contributed to this type of thermal mixing (13). Thus Narasimha Temple well exhibited homothermal stratification due to the mixing of water layers in the well.

\subsection{Hydrogen ion concentration}

\section{Physico-Chemical Parameters}

Hydrogen ion concentration for both the water bodies is on alkaline side. Masabi Boudi did not show the presence of $\mathrm{CO}_{2}$ whereas in Narasimha temple well, the concentration was very low. The observation indicates that the $\mathrm{pH}$ was controlled by carbonate and bicarbonate systems and in most of the time the equilibrium $\mathrm{CO}_{2}-, \mathrm{CO}_{3}$ - and $\mathrm{HCO}_{3}$ - was distributed. Free $\mathrm{CO}_{2}$ did not limit the $\mathrm{pH}$. This may be due to the large inputs of soaps and detergents. The study reveals that rains have caused the decrease in the concentrations of the above variables instead of dilution which is generally expected. In Narasimha Temple well $\mathrm{CO}_{3}$ was totally absent. The $\mathrm{pH}$ is controlled by $\mathrm{CO}_{2}$ and $\mathrm{HCO}_{3}^{-}$.

\subsection{Total alkalinity}

Total alkalinity is dependent on bicarbonates and carbonate concentrations. Higher total alkalinity which was observed in Narasimha Temple corresponds to the high bicarbonate concentration due to the extensive washing of clothes, temple wastes and its shallow nature. Total alkalinity may be due to bicarbonates and hydroxides because carbonates are absent in the study period. Total alkalinity in Masabi Boudi was in the same range except in the last three months it has shown a sudden increase. Alkalinity in this well may be due to carbonates, bicarbonates and hydroxides.

\subsection{Dissolved oxygen}

Dissolved oxygen concentration was not dependent on water temperature in Masabi Boudi whereas in Narasimha Temple well deeper strata exhibited inverse relation. Masabi Boudi exhibited very low concentrations of DO compared to Narasimha temple well. This may be due to the stratified nature. In Narasimha temple well average concentration indicate that oxygen was more at lower strata. $\mathrm{pH}$ also varied directly with DO indicating oxygen liberated during the photosynthesis and free carbon dioxide consumed ultimately increases the $\mathrm{pH}$ values.

\subsection{Nitrogenous contents}

Nitrogenous contents of both the wells are very high indicating rich nutritional status. Free ammonia concentration in Masabi Boudi was high at $9 \mathrm{mts}$ depth whereas in Narasimha temple well the surface water had high concentration. Free ammonia and nitrate were not significantly related except at few strata in Narasimha temple well, indicating the source of nitrate was probably the allochthonous material rather than by the oxidation of ammonia.

\subsection{Cationic concentrations}

Cationic concentrations of both the wells have shown very high values and were in the order of $\mathrm{Na}>\mathrm{K}>\mathrm{Mg}>\mathrm{Ca}$ in Narasimha temple well and in Masabi Boudi it was in the order of $\mathrm{Na}>\mathrm{Mg}>\mathrm{K}>\mathrm{Ca}$. An unusual concentration of $\mathrm{Mg}$ has been observed in both the wells. Narasimha temple well contains high concentrations of $\mathrm{Na}+$ and $\mathrm{K}+$ this may be due to senescing shoots of emerging macrophytes (14).

\subsection{Chloride concentration}

Chloride concentration was very high in both the wells indicating high level of pollution of animal origin. Monsoon periods exhibited high values and the amplitude of variation in both the wells was similar. Monsoon rains have caused a general increase in the concentration, instead of dilution and sometimes dilution was observed in summer period, which may be due to the addition of underground water through springs.

\subsection{Hardness of water}

Hardness of water bodies was not dependent on chloride, sodium or potassium, but it was related with magnesium, carbonates, bicarbonates, hydroxides, sulphates, etc. The higher the hardness values imparted the water with high buffer action and hence the water bodies with high hardness have exhibited low amplitude of variation of $\mathrm{pH}$. 


\subsection{Silica concentration}

Silica concentration in general was temperature dependent. High temperatures increased the silica concentration by which we can conclude that silica will be diffused into the water and will be distributed to all the strata in waters. Higher silica concentration has corresponded to increase in $\mathrm{pH}$ values. This confirms the reported literature in which the hydrolysis of silica which gives rise to silicic acid contributes to the rise in $\mathrm{pH}$.

\section{Phytoplankton}

An investigation of the communities inhabiting the water, therefore reveals the condition of the water and under the aspect of utilization of the water, the condition is also referred as quality condition. While physical and chemical conditions reveal the present condition, the biological analysis covers a longer period of the time because species of animals and plants are not subject to quick changes.

The study of phytoplankton ecology contributes to an understanding of the basic nature and general economy of the fresh water body. Generally a lake or a water body is considered as an ecological complex of a very high order or more briefly as an "Ecosystem" composed of biotopes and biocoenosis. However in spite of all the factors, the phytoplankton co-exist in a community and probably such is balanced more so in the tropical waters, whereas seasonal variations are not significant.

In the present study, the chlorococcales, desmidiales, euglenophyceae, bacillariophyceae and cyanophyceae were recorded with peculiar features of adaptability. Some species of the phytoplankton showed their maximum tolerance to the pollution of the water of two of the wells and is highly rich with nutrients and other chemicals, organic, inorganic and bio-chemical complexes.

A study on occurrence of few chlorococcales species in the different ranges of abiotic factors revealed that Scenedesmus dimorphus and S.arcuatus had the highest tolerance.

Desmids are considered to be strict aquatic fresh water algae, unable to withstand even apparently negligible quality of the aquatic habitat. The desmids had lesser periodicity in the present study. In general they were confined to the upper strata of the water column in the Masabi Boudi and they were absent in Narasimha Temple well. Desmids occurred almost throughout the year in Masabi Boudi.

In the present study, some taxa of the desmids however showed their pollution tolerant nature. Of the six species, three species were with constant tolerance with high temperatures and alkaline $\mathrm{pH}$. The study also indicated that Cosmarium margaritatium, C. laeve and C. Crenatum are highly pollution tolerant desmids.

The euglenophyceae represent a very sensitive group of flagellates and are the algae of hot season. They do not show their peculiar behavior towards physico-chemical factors and other complexes and are known for their occurrence in polluted waters and are dwellers of eutrophic waters rich in organic content.

In general, Euglena proxima and Tracelomonas volvocina were distributed in both the habitats.

The cyanophyceae are highly successful group and enjoy wide distribution in all kinds of habitats. They are probably predominant among the aboriginal organisms on the earth and are important both qualitatively and quantitatively. The present study shows that most of the nutrients increase during rains. Possibly Cyanophycean members utilize these nutrients during winter and increase in their population. The constant occurrence of Oscillators princes, Microcystis aeruginosa, Raphidiopsis and Anabaenopsis is an indication that the wells are all highly eutrophicated. These above taxa were highly resistant to various nutrient increases.

The diatoms are the most flexible organisms showing a wide range of adaptability. The diatoms also became predominant and resistant even in the organically rich water.

\section{Bio-Chemical And Bacteriological Studies}

The bacterioplankton population was studied with more importance to the count of Escherichia coli (Ecoli) as an indicator bacteria. As the wells are very old, lot of organic matter has been accumulated in water. Hence the water samples showed the presence of E-coli. These bacteria are the faecal bacteria present in the water contaminated by the sewage. Their mere presence itself indicates that the water body is polluted.

The microbial examination of the waters revealed that the total count of the E-coli and densities of bacterioplankton were related to water temperature, $\mathrm{pH}, \mathrm{DO}$, and DOM. In the present study optimum range for their growth was in the range of 26.2 to $26.7^{\circ} \mathrm{C}$. The E-coli being mesophylic, moderate alkaline $\mathrm{pH}$ had favoured the growth of E-coli in Masabi Boudi and Narasimha Temple well. Along with these the most enhancing factors for the growth of bacteria were organic complexes. Glucose and urea in higher concentrations were present in Narasimha Temple well, due to which the growth of E-coli was abundant.

In Masabi Boudi, E-coli count was at an annual average of 1310/100ml. in the month of October and from January onwards to September, the bacterial counts were highest up to 1750/100 $\mathrm{ml}$. In Narasimha Temple well, E-coli were maximum counting up to $1379 / 100 \mathrm{ml}$ on a yearly average. Their maximum was in summer and decreased in monsoon and winter. Bio-chemical characters like glucose, protein, urea, uric acid and creatinine which occur rarely in the well water have been observed in these historic wells. Similar 
observation was made by Venkateshwaralu et al (1990) (15) in which they have assessed physio-chemical, biological (phycological and bacteriological) and bio-chemical aspects of river Moosi to assess water pollution.

The source of bio-chemical substances like glucose and proteins, according to various reports are algal derivatives. Algae release extracellular organic compounds like glucose, protein, starch, cellulose and many other similar organic complexes which act as substrate for the bacterial growth (16).

The bacterioplankton and phytoplankton population were studied in relation with temperature, oxygen, dissolved organic matter, $\mathrm{pH}$ and other bio-chemical compounds like glucose, protein, urea, uric acid and creatinine were also studied.

Temperature- In Masabi Boudi the optimum temperature for their growth in summer was $26.5^{\circ} \mathrm{C}$ and in Narasimha Temple well $26.3^{\circ} \mathrm{C}$. Bacteria are sensitive to variations in $\mathrm{pH}$. They grow in the neutural or alkaline medium. In Masabi Boudi, in summer the $\mathrm{pH}$ was 8.8 and in Narasimha Temple well it was 9.2 which have favoured high growth of bacteria.

Dissolved Organic Matter- Increased mineralization of the organic matter induces primary production and increases particulate organic carbon (17). The two wells had high dissolved organic matter congenial for the growth of bacteria. From all the research works it is a known fact that, glucose is the most essential nutrient for the bacteria (17). Glucose is the end compound of photosynthetic activity by the planktonic algae. This is a natural substrate for bacteria.

In Narasimha Temple well, glucose and urea were more observed with protein, uric acid and creatinine. Hence the excess of glucose and urea along with others increased the growth of E-coli. When compared to Masabi Boudi, Narasimha Temple well is conspicuously favorable for the growth of bacteria, as the autochthonous organic material is increased due to the "floating meadow" supported by Rai (1979). Both allochthonous organic material added from the external source, temple waste have added autochthonous waste, have increased growth of bacteria. In Masabi Boudi, the phytoplanktonic algae are observed to be coinciding with the bacterial density. This conincidence of summer maxima of bacteria and phytoplankton suggests a closed interaction between phytoplankton and bacterioplankton (Oswald 1973). The algae supply the necessary factors for the growth of bacteria. In Narasimha Temple well, however, the bacteria alternated with the algal growth and bloom.

In the present study, the sensitivity of the eco-system of environmental factors greatly declines and a dynamic equilibrium is supported chiefly by the biotic interactions between dominant organisms.

On the whole, there is a beautiful and natural symmetry expressed in the biological science between the seasonal changes to the bacterioplankton and the phytoplankton of water. Thus in the present study, both the groups algae and bacteria were resistant to the environmental fluctuations. Closely coupled by the competitions, mutual separation and support. At this stage sensitivity of the ecosystem of environmental factor greatly declines and dynamic equilibrium is supported chiefly by the biotic interactions between the dominant organisms.

Thus the dominancy of E-coli in open wells clearly indicates the susceptibility of these wells to contamination. It is indicated that while coliform may die rapidly in clean streams, they can increase in numbers in polluted streams. Thus it seems that the high enrichment with organic matter provided a major stabilization to this ecosystem.

\section{VII . Conclusion}

Water quality and limnological studies of two fresh water habitats has revealed the nature's most interesting phenomenon of physio-chemical, bio-chemical, phyto \& bacterio planktonic structure to give the picture of the ecology and ecosystem. In the present study both the groups, algae and bacteria were resistant to environmental fluctuations closely coupled by competition, mutual separation and support. Ancient wells of Bijapur, Masabi Boudi and Narasimha Temple well have seen exceptional temperature results of inverse thermal vertical stratification and homothermal stratification. The phytoplanktonic study has shown the presence of pollution indicators like cyanophyceae and diatoms. Pollution tolerance is seen by the occurrence of Desmids (Fresh water indicators) which is of rare kind. The co-existence of algal bloom with the bacteria-Ecoli in Narasimha Temple well has the resultant assistance for the "floating meadow" of macrophytes. In this process, there is nature's purifying mechanism of water by circulation and oxygenating.

As Bijapur is a drought place in the Deccan plateau, the water of old wells can be used for recreation, gardening and converted into portable water. The heritage of Adil Shahis, thus can be protected and conserved with its natural source- WATER.

\section{Acknowledgement}

The authors are thankful to the Management of BLDE Association, Bijapur and to the UGC for providing financial assistance. 


\subsection{Table I}

\section{Tables}

Seasonal average values of physic-chemical factors of Masabi Boudi

\begin{tabular}{|c|c|c|c|c|c|c|c|c|c|c|c|c|c|}
\hline Seasons & & Winter & & & & Summer & & & & Monsoor & & & \\
\hline Sl.No & Factors & Surface & $3 \mathrm{mts}$ & $6 \mathrm{mts}$ & $9 \mathrm{mts}$ & Surface & $3 \mathrm{mts}$ & $\begin{array}{l}6 \\
\mathrm{mts}\end{array}$ & $\begin{array}{l}9 \\
\mathrm{mts}\end{array}$ & Surface & $3 \mathrm{mts}$ & $\begin{array}{l}6 \\
\mathrm{mts}\end{array}$ & $\begin{array}{l}9 \\
\mathrm{mts}\end{array}$ \\
\hline 1 & $\begin{array}{l}\text { Water } \\
\text { Temp }\end{array}$ & 24.5 & 24.5 & 24.7 & 24.5 & 26.5 & 26.25 & - & - & 28.0 & 27.5 & - & - \\
\hline 2 & $\mathrm{pH}$ & 8.15 & 8.32 & 8.3 & 8.1 & 8.9 & 8.8 & - & - & 10.5 & 10.5 & - & - \\
\hline 3 & $\begin{array}{l}\text { Carbon } \\
\text { Dioxide }\end{array}$ & - & - & - & - & - & - & - & - & - & - & - & - \\
\hline 4 & Carbonate & 18.0 & 15.6 & 17.4 & 4.8 & 17.4 & 18.0 & - & - & 21.0 & 18.6 & - & - \\
\hline 5 & $\begin{array}{l}\mathrm{Bi}- \\
\text { Carbonate }\end{array}$ & 203.5 & 207.9 & 211.0 & 158.0 & 229.0 & 235.0 & - & - & 265.9 & 281.5 & - & - \\
\hline 6 & $\begin{array}{l}\text { Total } \\
\text { Alkalinity }\end{array}$ & 197.5 & 196.5 & 202.0 & 174.0 & 217.0 & 223.0 & - & - & 253.0 & 262.0 & - & - \\
\hline 7 & D.O. & 7.3 & 4.05 & 4.35 & 1.8 & 4.05 & 4.35 & - & - & 8.25 & 5.85 & - & - \\
\hline 8 & $\begin{array}{l}\text { Org. } \\
\text { Matter }\end{array}$ & 11.77 & 12.72 & 11.8 & 17.5 & 10.7 & 10.9 & - & - & 10.5 & 11.0 & - & - \\
\hline 9 & Chlorides & 476.9 & 466.0 & 477.4 & 427 & 586.3 & 605.3 & - & - & 517.4 & 581.4 & - & - \\
\hline 10 & Hardness & 323.0 & 299.0 & 349.0 & 335.0 & 368.0 & 367.5 & - & - & 402.0 & 410.5 & - & - \\
\hline 11 & Calcium & 13.7 & 14.5 & 13.3 & 13.6 & 23.3 & 22.4 & - & - & 25.4 & 25.6 & - & - \\
\hline 12 & Magnesium & 72.7 & 66.5 & 78.5 & 76.5 & 81.6 & 80.5 & - & - & 88.7 & 90.4 & - & - \\
\hline 13 & Silica & 4.0 & 4.5 & 3.5 & 1.0 & 5.5 & 5.0 & - & - & 7.5 & 7.0 & - & - \\
\hline 14 & Free.Amm & 5.94 & 5.5 & 5.06 & 6.0 & 6.4 & 6.1 & - & - & 5.7 & 5.9 & - & - \\
\hline 15 & $\begin{array}{l}\text { Org } \\
\text { Nitrogen }\end{array}$ & 3.6 & 3.4 & 3.2 & 5.1 & 4.7 & 4.7 & - & - & 4.8 & 4.8 & - & - \\
\hline 16 & Phosphorous & 1.4 & 1.2 & 1.1 & 1.2 & 2.5 & 2.9 & - & - & 4.0 & 3.7 & - & - \\
\hline 17 & Nitrate & 7.8 & 5.9 & 6.5 & 7.1 & 2.6 & 3.1 & - & - & 5.3 & 4.1 & - & - \\
\hline 18 & Sodium & 425.3 & 428.7 & 425.3 & 435.6 & 376.4 & 374.7 & - & - & 305.7 & 310.3 & - & - \\
\hline 19 & Potassium & 42.3 & 49.0 & 56.6 & 69.0 & 58.8 & 56.1 & - & - & 51.3 & 53.9 & - & - \\
\hline
\end{tabular}

\subsection{Table II}

Seasonal average values of physic-chemical factors of Narasimha Temple well

\begin{tabular}{|c|c|c|c|c|c|c|c|c|c|c|c|c|c|}
\hline \multirow{2}{*}{$\begin{array}{l}\text { Seasons } \\
\text { Sl.No }\end{array}$} & \multirow{2}{*}{ Factors } & \multicolumn{4}{|l|}{ Winter } & \multicolumn{4}{|l|}{ Summer } & \multicolumn{4}{|c|}{ Monsoon } \\
\hline & & Surface & $3 \mathrm{mts}$ & $6 \mathrm{mts}$ & $9 \mathrm{mts}$ & Surface & $3 \mathrm{mts}$ & $\begin{array}{l}6 \\
\mathrm{mts}\end{array}$ & $\begin{array}{l}9 \\
\mathrm{mts}\end{array}$ & Surface & $3 \mathrm{mts}$ & $\begin{array}{l}6 \\
\mathrm{mts}\end{array}$ & $\begin{array}{l}9 \\
\mathrm{mts}\end{array}$ \\
\hline 1 & $\begin{array}{l}\text { Water } \\
\text { Temp }\end{array}$ & 26.5 & 25.0 & 23.7 & 25.0 & 26.7 & 26.5 & - & - & 28.5 & 28.0 & - & - \\
\hline 2 & $\mathrm{pH}$ & 8.0 & 7.9 & 8.0 & 7.3 & 9.2 & 9.2 & - & - & 10.1 & 10.3 & - & - \\
\hline 3 & $\begin{array}{l}\text { Carbon } \\
\text { Dioxide }\end{array}$ & 13.9 & 14.8 & 18.4 & 5.9 & 19.9 & 18.9 & - & - & 27.9 & 23.9 & - & - \\
\hline 4 & Carbonate & - & - & - & - & - & 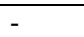 & - & - & - & - & - & - \\
\hline 5 & $\begin{array}{l}\text { Bi- } \\
\text { Carbonate }\end{array}$ & 260.4 & 268.3 & 275.1 & 243.9 & 238.4 & 242.7 & - & - & 260.4 & 266.5 & - & - \\
\hline 6 & $\begin{array}{l}\text { Total } \\
\text { Alkalinity }\end{array}$ & 213.5 & 220.3 & 225.5 & 200.0 & 195.5 & 199.0 & - & - & 213.5 & 218.5 & - & - \\
\hline 7 & D.O. & 7.5 & 3.9 & 4.3 & 1.8 & 4.7 & 5.2 & - & - & 12.0 & 8.5 & - & - \\
\hline 8 & $\begin{array}{l}\text { Org. } \\
\text { Matter }\end{array}$ & 11.9 & 12.0 & 10.3 & 17.0 & 8.8 & 8.7 & - & - & 6.8 & 8.5 & - & - \\
\hline 9 & Chlorides & 575.3 & 582.8 & 609.3 & 499.4 & 534.2 & 481.8 & - & - & 507.5 & 510.0 & - & - \\
\hline 10 & Hardness & 380.5 & 392.5 & 402.0 & 350.0 & 421.0 & 382.5 & - & - & 396.0 & 379.5 & - & - \\
\hline 11 & Calcium & 13.7 & 14.1 & 15.3 & 13.9 & 23.2 & 15.0 & - & - & 22.6 & 22.3 & - & - \\
\hline 12 & Magnesium & 84.4 & 86.8 & 88.6 & 64.7 & 93.1 & 85.6 & - & - & 87.8 & 86.5 & - & - \\
\hline 13 & Silica & 1.0 & 2.5 & 2.0 & 0.0 & 2.5 & 2.6 & - & - & 7.5 & 6.5 & - & - \\
\hline 14 & Free.Amm & 3.5 & 4.0 & 3.1 & 2.8 & 1.9 & 2.4 & - & - & 5.2 & 4.3 & - & - \\
\hline 15 & $\begin{array}{l}\text { Org } \\
\text { Nitrogen }\end{array}$ & 3.6 & 3.2 & 2.7 & 4.1 & 3.4 & 3.6 & - & - & 3.8 & 4.3 & - & - \\
\hline 16 & Phosphorous & 1.7 & 1.7 & 1.9 & 1.4 & 1.4 & 1.7 & - & - & 2.7 & 1.7 & - & - \\
\hline 17 & Nitrate & 6.8 & 5.4 & 5.3 & 3.5 & 5.0 & 5.7 & - & - & 6.3 & 6.3 & - & - \\
\hline 18 & Sodium & 390.8 & 414.3 & 423.0 & 424.4 & 339.6 & 334.1 & - & - & 421.8 & 417.2 & - & - \\
\hline 19 & Potassium & 194.5 & 201.3 & 212.0 & 246.3 & 288.3 & 289.3 & - & - & 154.3 & 154.2 & - & - \\
\hline
\end{tabular}




\subsection{Table III}

Seasonal distribution of Algae and Bacteria

\begin{tabular}{|l|l|l|l|l|l|l|}
\hline Plankton & Masabi Boudi & \multicolumn{3}{l|}{ Narasimha Temple well } \\
\hline & Winter & Summer & Monsoon & Winter & Summer & Monsoon \\
\hline Algae & 926.5 & 869.6 & 616.1 & 1475.1 & 739.9 & 1176.6 \\
\hline Bacteria & 570.0 & 1750.0 & 1600.0 & 1225.0 & 1487.5 & 1425.0 \\
\hline
\end{tabular}

\subsubsection{Annual average of algae and bacteria}

\begin{tabular}{|l|l|l|}
\hline Plankton & Masabi Boudi & Narasimha Temple well \\
\hline Algae & 2924 & 1025 \\
\hline Bacteria & 19650 & 20200 \\
\hline
\end{tabular}

\section{References}

\section{Journal Papers:}

[1] HUTCHINSON, G.E. 1975 A. Treatise on Lymnology, Vol II. John Wiley and Sons, New York.

[2] JANA, B.B. 1979 Temporal Plankton Succession and Ecology of a Tropical Tank In West Bengal. Int. Reve. Ges. Hydrobiol. 64: $661-671$

[3] SPURR B. 1975 Lymnology of BirdPondRossIslandAntarctica N.Z.J. Marland Fresh Water Res, 2 (4): $547-572$

[4] KHAN. M. A \& D.P.ZUTSHI,1980 Primary Productivity \& tropic status of KashmirHimalayanLake Hydro-Biologia 68-38

[5] JYOTI. M. K, H.S. SEHGAL \& P.S.SODHI 1986 Thermal Ecology of Surinsar. A Sub-Tropical Fresh Water lake In Jammu, India. Polskie Archiwum Hydro-Biologia 33 (1): 9-20

[6] KAUL.V.J.K. HANDOO R. Raina, 1980 Physio-Chemical characteristics of Nilang- A High Altitude forest Lake In Kashmir. Proc. Indian Nat Sci Acad B 16 (4). 528-541

[7] MUNAWAR.M. and A.R.ZAFAR, 1967. Apreliminary study of vertical Movement of Eudorina elegans during a bloom caused by them. Hydrobiologia. 29(1-2):140-148.

[8] ZAFAR.A.R. 1968 .Certain Aspects of Distribution Pattern of Phytoplankton in the lakes of Hyderabad. Proc. Symp. Recent Adv. Trop. Ecol: 368-375

[9] GEORGE. M. G. 1961 Diurnal Variations in Two Shallow Ponds in Delhi, India Hydro-Biologia. 18 (3) 265-273

[10] DAVIS.C.C 1973 A Seasonal Quantitative Study Of the Phytoplankton of Bauline Long Pond, A New Found LandLake. Le Naturaliste Can. 100: 85-105

[11] SHRINIVASAN A. R. SUNDER RAJ and T. Franklin 1973 Diurnal and Seasonal Changes in a Productive Shallow Tropical Pond. Phykos. 12 (1-2): 86-103

[12] SHARMA. K. P., P. K. GOEL \& B. GOPAL 1972 Lymnological Studies Of Polluted Fresh Water. Physio-Chemical Characteristics. Int. J. Ecol. Environ. Sci. 4: 89-105

[13] SCHOL.Z.O 1990 Physico- Chemistry and Vegetation of Piccaninnie Ponds. A Coastal Aquifer-Fed Pond in South-Eastern South Aust. J. Mar. Fresh. Res. 41: 237-246

[14] VENKATESHWARALU. V. P. T. SAMPATHKUMAR \& J. NIRMALKUMARI 1990 Ecology of Algae in the River Moosi, Hyderabad- A Comprehensive Study J. Environ. Biol 11 (1): 79-91

[15] RAI. H. \& G. HILL 1982 On The Nature of The Ecological Cycle Of Lago Jananari: A central Amazonian. Rai/ Varzea. Tropical. Ecol. 23 (1) : $1-50$

[16] RAI. H. 1979 Glucose in Fresh Water of CentralAmazonLakes: Natural Substrate Concentrations. Determined by Dilution Of Bioassay. Int. Revue. ges. Hydrobiol 64 (1): 141-146 